\title{
Gebelerde proteinüri tanısında kullanılan yöntemlerin karşılaştırılması
}

\section{Comparison of methods used in the diagnosis of proteinuria in pregnant women}

iD Ersin Çintesun ${ }^{1}$, iD Mete Bertizlioğlu ${ }^{1}$, iD Mete Can Ateş ${ }^{1}$, iD Abdul Hamid Güler ${ }^{1}$, iD Çetin Çelik ${ }^{1}$.

${ }^{1}$ Selçuk Üniversitesi Tıp Fakültesi Kadın Hastalıkları ve Doğum Anabilim Dalı

\section{$\ddot{O} z$}

Amaç: Preeklampsi ön tanısı ile kliniğimizde tetkik ve tedavi edilen gebelerin proteinüri tanısında kullanılan yöntemlerin karşılaştırılmasıı amaçlanmıștır.

Gereç ve yöntem: Çalışmaya, Ocak 2016-Aralık 2018 tarihleri arasında bir üniversite hastanesinde preeklampsi ön tanısı ile spot idrarda dipstik yöntemi, P/K oranı ve 24 saatlik idrarda toplam protein analizi yapılan 317 hasta çalışmaya dahil edildi. Hastaların bu üç değeri birbiri ile mukayese edildi.

Bulgular: 24 saatlik idrarda toplam proteinüri eşik değeri $300 \mathrm{mg} /$ gün olduğunda $\mathrm{P} / \mathrm{K}$ oranı cut-off değeri $0,34 \mathrm{mg}$ protein/mg kreatinin, sensitivite $\% 68,9$, spesifite $\% 78,7$ olarak hesaplandı. Spot idrar P/K oranı ile 24 saatlik idrardaki toplam proteinüri değerleri arasında orta düzeyde kuvvetli, istatistiksel olarak anlamlı korelasyon saptand $(\mathrm{r}=0,629 \mathrm{p}<0,001)$.

Sonuç: 24 saatlik toplam idrar analizi için yeterli zamanın olmadığı acil durumlarda spot idrarda $\mathrm{P} / \mathrm{K}$ oranının 24 saatlik idrarda toplam protein testine alternatif test olarak kullanılabilir

Anahtar kelimeler: gebe, idrar, proteinüri, preeklampsi, protein/kreatinin oranı

\begin{abstract}
Objective: The aim of this study was to compare the total protein content in 24 hours urine with dipstic, protein / creatinine (P / K) ratio in spot urine in our pregnant women who were diagnosed with preeclampsia.

Material and Methods: In this study, 317 patients who underwent dipstick method, P / K ratio and total protein analysis in 24-hour urine were included in the study with a prediagnosis of preeclampsia at a university hospital gynecology and obstetrics clinic between January 2016 and December 2018 . These three values of patients were compared with each other
\end{abstract}

Results: When the total proteinuria threshold in the 24-hour urine was $300 \mathrm{mg} /$ day, the P-C ratio cut-off value was $0.34 \mathrm{mg}$ protein / mg creatinine, the sensitivity was $68.9 \%$ and the specificity was $78.7 \%$. A moderate, significant correlation was observed between total urinary $\mathrm{P} / \mathrm{K}$ ratio and total proteinuria in 24-h urine $(\mathrm{r}=0.629 \mathrm{p}<0.001)$.

Conclusion: It can be used as an alternative test in the 24-hour urine total protein test of $\mathrm{P} / \mathrm{C}$ ratio in spot urine in emergencies where there is not enough time for 24 hour total urine analysis.

Keywords: pregnant, urine, proteinuria, preeclampsia, protein / creatinine ratio.

Yazıșma Adresi: Ersin Çintesun, Selçuk Üniversitesi Tıp Fakültesi Kadın Hastalıkları ve Doğum Anabilim Dalı ,42030, Konya Türkiye

E-Posta: ersincintesun@gmail.com

Alınma Tarihi : 25.09.2019 / Kabul Tarihi : 22.06.2020 / Yayımlanma Tarihi : 15/06/2021

Gebelerde proteinüri tanı yöntemleri - Çintesun ve ark. 


\section{Giriş}

Preeklampsi (PE) çoğunlukla gebeliğin 20. haftasından sonra ortaya çıkan, hipertansiyon, proteinüri veya end organ hasarı ile karakterize tüm vücut sistemlerini etkileyebilen, ilerleyici bir hastalıktır. PE hem anne hem de fetus için yüksek riskli bir hastalıktır $(1,2)$. PE hastalığının kesin tedavisi doğum olup, tanıda geç kalınması durumda hem anne hem de fetüs için ciddi morbidite ve mortalite sebebi olabilmektedir.

Günümüzde PE tanısında kesin bir tanı metodu bulunmamaktadır. Ancak; proteinüri, preeklampsi tanısında sıklıkla kullanılan bir tanı metodudur (3-5). Gebelikte kullanılan proteinüri eşik değerleri sağlıklı erişkinlerden farklıdır. Gebelikte meydana gelen fizyolojik değişiklikler sebebi ile gebe olmayan sağlıklı erişkinlerdeki $150 \mathrm{mg} /$ gün proteinüri sınırı gebelerde $300 \mathrm{mg} /$ gün olarak belirlenmiştir (3, 6). Proteinüri tanısında kullanılan yöntemler: dipstik yöntemi, spot idrarda protein/kreatinin oran 1 ve 24 saatlik idrarda toplam protein analizidir. $\mathrm{Bu}$ yöntemlerin her birinin avantajı ve dezavantajı bulunmakla birlikte altın standart tanı yöntemi olarak 24 saatlik idrarda toplam protein analizi kabul edilmektedir $(7,8)$. Dipstik yöntemi ve protein kreatinin oranları ile çalışmalar ve kesme değeri bulunmaktadır $(9,10)$. Bu çalışmada amacımız kliniğimizde bu üç yöntemin aynı anda kullanıldığı hasta verilerinden kendi kliniğimiz verilerinin doğruluğu test etmek ve kesme değerlerini belirlemektir.

\section{Materyal ve Metodlar}

Çalışmamız bir retrospektif bir çalışmadır. Çalışma için Selçuk Üniversitesi lokal etik kuruldan izin alındı (Kayıt no: 2019/204). 1 Ocak 2016- 31 Aralık 2018 yıllarında Selçuk Üniversitesi kadın hastalıkları ve doğum kliniğinde proteinüri veya PE ön tanısı ile tetkik edilmiş 317 hasta çalışmaya dahil edildi. Çalışmaya proteinüriye sebep olabilecek sistemik hastalığı olan, gebelik öncesi proteinürisi olan hastalar çalışma dışında bırakıldı. Ayrıca her üç tanı metodu uygulanmayan hastalar da çalışmaya dahil edilmedi. Aynı dönemde yapılmış spot idrarda dipstik, protein/ kreatinin oranı ve 24 saatlik idrarda toplam protein değerleri incelendi. Spot idrar dipstikte değerler negatif, eser, $+1,+2,+3$ olarak alındı. Negatif ve eser proteinüri raporlanan olgular proteinüri negatif, diğerleri ise proteinüri pozitif olarak kabul edildi. 24 saatlik idrar sonucu $300 \mathrm{mg} /$ gün ve üzeri olan olgular proteinüri pozitif olarak çalışmaya alındı. Protein/ kreatinin oranı ile 24 saatlik idrardaki proteinüri analizinde farklı eşik değerleri kullanıldı. Çalışma analizinde 24 satlik idrar analizi sonuçları altın standart tanı testi olarak kabul edildi.

İstatistiksel analizler için, IBM SPSS versiyon 21 (SPSS Inc., Chicago, IL, ABD) kullanıldı. Normal dağılım değerlendirilmesi için histogram ve Kolmogorov-Smirnov testleri kullanıldı. Spot idrarda protein/ kreatinin oranı ile 24 saat idrarda protein değeri karşılaştırılmasında korelasyon analizi için Spearman korelasyon analizi kullanıldı. Farklı 24 saatlik idrarda toplam protein değerleri için $\mathrm{P} / \mathrm{K}$ oranının kesme değerleri, spesifite, sensitivite analizi hesaplandi. Spesifite ve sensitivite analizi için ROC (Reciever Operator Characteristics Curve) analizi kullanıldı. İstatistiksel anlamlılık düzeyi $\mathrm{p}<0,05$ olarak kabul edildi.

\section{Bulgular}

Ortalama yaş $26,1 \pm 5,1$ olarak hesaplandi. Spot idrarda dipstick analizinin ROC analizi ile ilgili analiz verileri Tablo 1'de özetlenmiştir. 24 saatlik idrarda proteinüri için kesme değeri $\geq 300 \mathrm{mg} /$ gün ve Dipstik yöntemi için proteinüri sınırı +1 ve üzeri değerler alındı.
Dipstik yöntemindeki proteinüri için 24 saatlik idrar sonucunun kesme değeri $\geq 0,34 \mathrm{mg}$ protein $/ \mathrm{mg}$ kreatinin; EAA 0.787, sensitivitesi $\% 68,9$; spesifitesi $\% 78,7$; doğruluğu $\% 74,1$ olarak hesapland1.

Tablo 1. Dipstik yönteminin ROC analizi

\begin{tabular}{|l|l|l|l|l|l|}
\hline & Kesme değeri & EAA & P değeri & Sensitivite & Spesifite \\
\hline Disptick & $\geq 0,34 \mathrm{mg} /$ gün & $0.787(0,737-0,836)$ & $<0,001$ & $\% 68,9$ & $\% 78,7$ \\
\hline
\end{tabular}

Dipstik analizinde negatif, eser değerler negatif, $+1,+2,+3$ değerleri ise pozitif olarak alındi. 24 saatlik idrarda proteinüri $\geq 300 \mathrm{mg} /$ gün olarak alındı. EAA: Eğri altındaki alan,; GA: Güven aralığı

24 saatlik idrar analizinde proteinüri eşik değerlerinin farklı alınması sonucu $\mathrm{P} / \mathrm{K}$ oranı eşik değer, spesifite, sensitivite değerleri Tablo 2 ve Şekil 1 de özetlenmiştir. 24 saatlik idrarda toplam proteinüri eşik değeri $300 \mathrm{mg} /$ gün iken $\mathrm{P} / \mathrm{K}$ oranı kesme değeri $0,34 \mathrm{mg}$ protein $/ \mathrm{mg}$ kreatinin, sensitivite $\% 68,9$, spesifite $\% 78,7 ; 500 \mathrm{mg} /$ gün iken $\mathrm{P} / \mathrm{K}$ oranı cut-off değeri $0,49 \mathrm{mg}$ protein $/ \mathrm{mg}$ kreatinin, sensitivite $\% 79,8$, spesifite $\% 81,6 ; 1000 \mathrm{mg} /$ gün iken $\mathrm{P} / \mathrm{K}$ oran cut-off değeri $0,67 \mathrm{mg}$ protein $/ \mathrm{mg}$ kreatinin, sensitivite $\% 92,5$, spesifite $\% 85,6 ; 3500 \mathrm{mg} /$ gün iken $\mathrm{P} / \mathrm{K}$ oran1 cut-off değeri $1,16 \mathrm{mg}$ protein/mg kreatinin, sensitivite $\% 100$, spesifite $\% 91,0$ olarak hesapland.
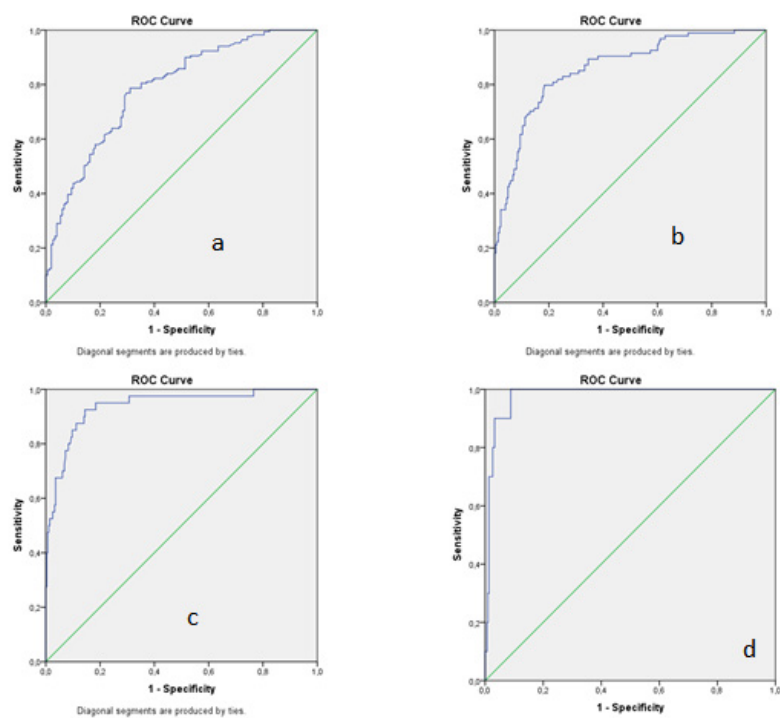

Şekil 1. 24 saatlik idrardaki toplam proteinüri değerlerinin farklı cutoff değerlerine göre ROC eğrileri $a: \geq 300 \mathrm{mg} /$ gün; $b \geq 500 \mathrm{mg} /$ gün; c $\geq 1000 \mathrm{mg} /$ gün; $d \geq 3500 \mathrm{mg} /$ gün proteinüri. ROC: Receiver operating characteristic

Spot idrar $\mathrm{P} / \mathrm{K}$ oranı ile 24 saatlik idrardaki toplam proteinüri değerlerinin korelasyon eğrisi Şekil 2' de özetlenmiştir. Bu iki değer arasında orta düzeyde, anlamlı bir korelasyon gözlendi $(r=0,629$ $\mathrm{p}<0,001)$. 
Tablo 2. Preeklampsinin ciddiyetini öngören diskriminant spot idrar protein/kreatin oranları

\begin{tabular}{lccccc}
\hline $\begin{array}{l}\text { 24 saatlik idrarda } \\
\text { toplam proteinüri } \\
\text { sinırı (mg/gün) }\end{array}$ & EAA & $\begin{array}{c}\text { P/K Oranı (mg/ } \\
\text { mg) kesme } \\
\text { değerleri }\end{array}$ & Sensitivite(\%) & Spesifite(\%) & p değeri \\
\hline$\geq 300$ & 0.787 & $\geq 0,34$ & 68.9 & 78.7 & $<0.001$ \\
$\geq 500$ & 0.859 & $\geq 0,49$ & 79.8 & 81.6 & $<0.001$ \\
$\geq 1000$ & 0.938 & $\geq 0,67$ & 92.5 & 85.6 & $<0.001$ \\
$\geq 3.500$ & 0.979 & $\geq 1,16$ & 100 & 91.0 & $<0.001$ \\
\hline
\end{tabular}

EAA: Eğrinin altındaki alan; $\mathrm{P} / \mathrm{K}$ oranı: Protein kreatin oranı; ROC: Receiver operating characteristic.

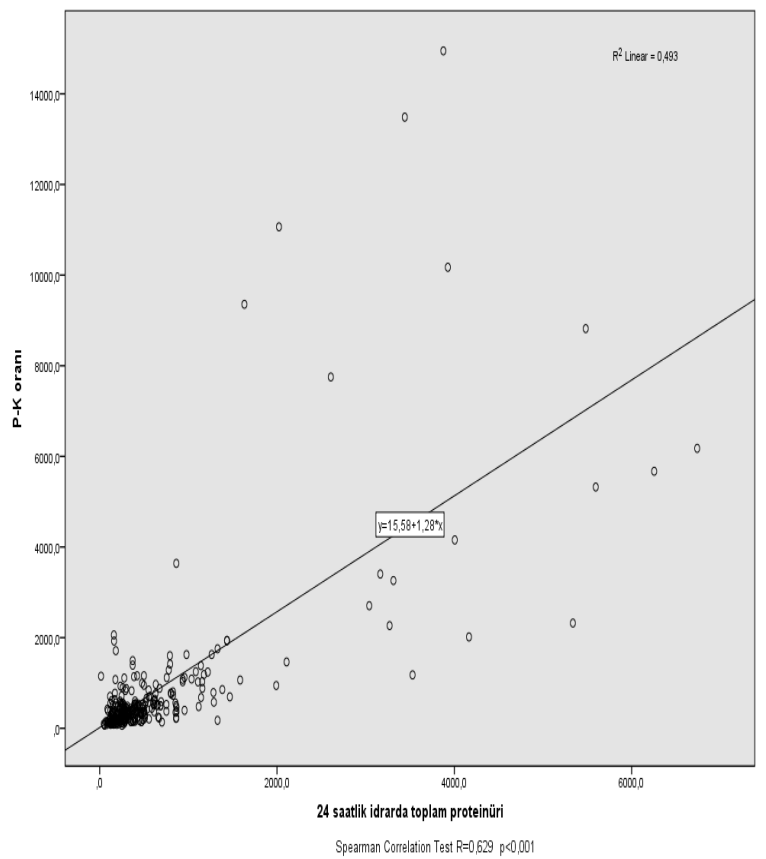

Şekil 2: Spot idrar $\mathrm{P} / \mathrm{K}$ oranı ile 24 saatlik idrardaki proteinüri korelasyon grafiği

\section{Tartışma}

Çalışmamızda, anlamlı proteinüri saptanmasında $\mathrm{P} / \mathrm{K}$ oranı kesme değeri $0,34 \mathrm{mg}$ protein/mg kreatinin, sensitivite $\% 68,9$, spesifite $\%$ 78,7 olarak hesaplandi. Ayrıca P/K oranı ile 24 saatlik idrarda toplam proteinüri arasında orta düzeyde, anlamlı korelasyon bulunmuştur ( $r$ $=0,629, \mathrm{P}<0,001)$.

Proteinüri tanısı hem PE tanısında hem de yönetiminde kullanılan önemli bir tanı aracıdır. Proteinüri tanısında çok sayıda tanı metodu bulunmaktadır. Semikantitatif ve kantitatif analiz yöntemleri bulunmaktadır. Semikantitatif tanı yöntemi olarak dipstik ile spot idrarda protein analizi sıklıkla kullanılırken; kantitatif tanı yöntemi olarak spot idrarda $\mathrm{P} / \mathrm{K}$ oranı ve 24 saatlik idrarda toplam proteinüri kullanılmaktadır.

Dipstik yöntemi basit, ucuz ve hızlı bir tanı yöntemi olmasına rağmen tanıda spesifite ve sensitivitesi sinırlıdır $(7,11)$. Semikantitatif bir yöntem olan dipstik yöntemi, idrarda öncelikle albumin analizi ile sonuç vermektedir. Ayrıca dipstik yönteminde yüksek oranda yalancı pozitif ve negatif sonuçlar görülmektedir $(7,12,13)$. İdrar dansitesi, asiditesi, hematüri varlığı, ilaç kullanımı gibi birçok durum sonuca etki etmektedir $(7,12,13)$. Dipstik yönteminin sensitivitesi \% 67,5, spesifitesi \% 61,5 olarak bulundu. Dipstik yönteminin kullanımı hem literatürde hem de çalışmamızda PE gibi hayati bir hastalık tanısında kullanımı için tek başına güçlü bir yöntem olmadığı görülmektedir.

Proteinüri tanısında 24 saatlik idrarda toplam protein analizi, spot idrarda protein/kreatinin oranı ve spot idrarda albumin/kreatinin oranı kantitatif tanı yöntemleridir. 24 saatlik idrarın yetersiz veya fazla biriktirilmesi sorunlarının olması, tanı için 24 saat veya daha fazla süre beklenmesinin gerekiyor olması kısıtlayıcı özelliği olsa da PE tanısında gold standart tanı yöntemi olarak kabul edilmektedir $(8,14$, $15)$.

$\mathrm{P} / \mathrm{K}$ oranı PE tanısında kullanılan başka bir analiz olup, spot idrar analizi ile elde edilen bir tanı yöntemidir. P/K oranının PE tanısında etkili bir yöntem olduğu birçok çalışmada gösterilmiştir (16-19). Spot idrarda $\mathrm{P} / \mathrm{K}$ oranı rutin pratikte sıklıkla kullanılmaya başlanmasına rağmen aşikar proteinüriyi göstermekte net bir sınır değeri mevcut değildir $(14,16,19,20)$. Cote ve arkadaşlarının yaptığı, 13 çalışmanın metaanalizinde $\mathrm{P} / \mathrm{K}$ oranı cut-off değeri $0,26 \mathrm{mg}$ protein/mg kreatinin; sensitiviteyi \%83,6; spesifiteyi \% 76,3 olarak bulunmuşken; Morris ve arkadaşlarının yaptığı başka bir metaanalizde ise $\mathrm{P} / \mathrm{K}$ oranı cut-off değeri $0,30 \mathrm{mg}$ protein $/ \mathrm{mg}$ kreatinin; sensitiviteyi $\% 81$; spesifiteyi $\%$ 76 olarak bulmuşlardır $(20,21)$. Literatürde oldukça farklı değerler bulan çalışmalar da mevcuttur. Örneğin Kucukgoz arkadaşları yaptığı çalışmada $\mathrm{P} / \mathrm{K}$ oranı cut-off değeri $0,53 \mathrm{mg}$ protein $/ \mathrm{mg}$ kreatinin olarak hesaplamışlardır (16). Ancak birçok dernek P/K oranı cut-off değerini 0,26-0,30 olarak kabul etmektedir $(22,23)$. Çalışmamızda 24 saatlik idrarda toplam proteinüri için sınır değeri $300 \mathrm{mg} /$ gün ve üzeri alındığında $\mathrm{P} / \mathrm{K}$ oranı cut-off değeri $0,34 \mathrm{mg}$ protein $/ \mathrm{mg}$ kreatinin; $500 \mathrm{mg} /$ gün alındğında $0,49 \mathrm{mg}$ protein/mg kreatinin; $1000 \mathrm{mg} /$ gün alındığında $0,67 \mathrm{mg}$ protein $/ \mathrm{mg}$ kreatinin; $3500 \mathrm{mg} /$ gün alındığında ise $1,16 \mathrm{mg}$ protein/mg kreatinin olarak bulundu. Çalışmamızda literatür verilerine yakın bir kesme değeri elde edilmiştir.

Çalışmamızda dipstik yöntemi ve spot idrarda $\mathrm{P} / \mathrm{K}$ oranı sensitivite oranları benzer ve spesifite oranları ise spot idrarda $\mathrm{P} / \mathrm{K}$ oranı lehine yüksek bulunmuştur. Literatür incelendiğinde dipstik yöntemini etkileyen çok sayıda anlık değişken izlenmiş olması ve spot idrar $\mathrm{P} / \mathrm{K}$ oranlarının da yüksek doğruluk ve tekrarlanabilir olması sebebi ile spot idrarda $\mathrm{P} / \mathrm{K}$ oranı preeklampsi tanısında daha güvenilir bir yer etmektedir $(7,12,13,24)$. Ancak dipstik yönteminin basit, ucuz, kolay uygulanabilir olması sebebi ile ilk basamak taramada kullanılması ve şüpheli durumlarda spesifitesi daha yüksek yöntemlere başvurulması maliyet etkin bir yaklaşım olacaktır.

Çalı̧̧mamızın limitasyonu retrospektif bir çalışma olması, olgu sayısının az olması ve kliniğimizde bu üç yöntemin aynı dönemde istendiği hastaların çalışmaya dahil edilip, tüm preeklamptik hastaların çalışmaya dahil edilememiş olmasıdır.

Sonuç olarak çalışmamızda 24 saatlik idrarda toplam protein miktarı ile spot idrarda $\mathrm{P} / \mathrm{K}$ oranının korele olduğunu izlendi. Dipstik yönteminin spot idrarda $\mathrm{P} / \mathrm{K}$ oranının benzer sensitivitede olduğu gözlendi. Tarama yöntemi olarak dipstik yöntemi kullanılabilir ve ayırıcı tanıda spot idrarda $\mathrm{P} / \mathrm{K}$ oranının 24 saatlik idrarda protein testine alternatif test

olabileceği düşünülebilir. Kliniğimizde $\mathrm{P} / \mathrm{K}$ oranı kesme değeri 0,34 $\mathrm{mg}$ protein/mg kreatinin olarak bulundu. 


\section{Kaynaklar}

1. von Dadelszen P, Magee LA. Preventing deaths due to the hypertensive disorders of pregnancy. Best practice \& research Clinical obstetrics \& gynaecology. 2016;36:83-102.

2. Harmon QE, Huang L, Umbach DM, Klungsoyr K, Engel SM, Magnus P, et al. Risk of fetal death with preeclampsia. Obstetrics and gynecology. 2015;125(3):628-35.

3. Higby K, Suiter CR, Phelps JY, Siler-Khodr T, Langer O. Normal values of urinary albumin and total protein excretion during pregnancy. American journal of obstetrics and gynecology. 1994;171(4):984-9.

4. Sibai BM. Eclampsia. VI. Maternal-perinatal outcome in 254 consecutive cases. American journal of obstetrics and gynecology. 1990;163(3):1049-54; discussion 54-5.

5. Thornton CE, Makris A, Ogle RF, Tooher JM, Hennessy A. Role of proteinuria in defining pre-eclampsia: clinical outcomes for women and babies. Clinical and experimental pharmacology \& physiology. 2010;37(4):466-70

6. Roberts M, Lindheimer MD, Davison JM. Altered glomerular permselectivity to neutral dextrans and heteroporous membrane modeling in human pregnancy. The American journal of physiology. 1996;270(2 Pt 2):F338-43.

7. Waugh JJ, Clark TJ, Divakaran TG, Khan KS, Kilby MD. Accuracy of urinalysis dipstick techniques in predicting significant proteinuria in pregnancy. Obstetrics and gynecology. 2004;103(4):769-77.

8. Cote AM, Firoz T, Mattman A, Lam EM, von Dadelszen P, Magee LA. The 24-hou urine collection: gold standard or historical practice? American journal of obstetrics and gynecology. 2008;199(6):625.e1-6.

9. Alkan O, Ozkok A, Ozportakal H, Bulut AS, Isman F, Odabas AR. Spot urine protein creatinine ratio is associated with 24-hour proteinuria and serum albumin. Medeniye Medical Journal. 2016;31(4):241-4.

10. Higby K, Suiter CR, Phelps JY, Siler-Khodr T, Langer O. Normal values of urinary albumin and total protein excretion during pregnancy. American journal of obstetrics and gynecology. 1994;171(4):984-9.

11. Harlow FH, Brown MA. The diversity of diagnoses of preeclampsia. Hypertension in pregnancy. 2001;20(1):57-67.

12. Baba Y, Yamada T, Obata-Yasuoka M, Yasuda S, Ohno Y, Kawabata K, et al. Urinary protein-to-creatinine ratio in pregnant women after dipstick testing: prospective observational study. BMC pregnancy and childbirth. 2015;15:331.

13. Baba Y, Furuta I, Zhai T, Ohkuchi A, Yamada T, Takahashi K, et al. Effect of urine creatinine level during pregnancy on dipstick test. J Obstet Gynaecol Res. 2017;43(6):96773 .

14. Kayatas S, Erdogdu E, Cakar E, Yilmazer V, Arinkan SA, Dayicioglu VE. Comparison of 24-hour urinary protein and protein-to-creatinine ratio in women with preeclampsia. European journal of obstetrics, gynecology, and reproductive biology. 2013;170(2):36871.

15. Boyd C, Wood K, Whitaker D, Ashorobi O, Harvey L, Oster R, et al. Accuracy in 24-hour Urine Collection at a Tertiary Center. Reviews in urology. 2018;20(3):119-24

16. Kucukgoz Gulec U, Sucu M, Ozgunen FT, Buyukkurt S, Guzel AB, Paydas S. Spot Urine Protein-to-Creatinine Ratio to Predict the Magnitude of 24-Hour Total Proteinuria in Preeclampsia of Varying Severity. Journal of obstetrics and gynaecology Canada $:$ JOGC $=$ Journal d'obstetrique et gynecologie du Canada : JOGC. 2017;39(10):854 60 .

17. Waugh J, Hooper R, Lamb E, Robson S, Shennan A, Milne F, et al. Spot protein-creatinine ratio and spot albumin-creatinine ratio in the assessment of pre-eclampsia: a diagnostic accuracy study with decision-analytic model-based economic evaluation and acceptability analysis. Health technology assessment (Winchester, England). 2017;21(61):1-90.

18. Price CP, Newall RG, Boyd JC. Use of protein:creatinine ratio measurements on random urine samples for prediction of significant proteinuria: a systematic review. Clinical chemistry. 2005;51(9):1577-86.

19. Shahbazian N, Hosseini-Asl F. A comparison of spot urine protein-creatinine ratio with 24-hour urine protein excretion in women with preeclampsia. Iranian journal of kidney diseases. 2008;2(3):127-31.

20. Cote AM, Brown MA, Lam E, von Dadelszen P, Firoz T, Liston RM, et al. Diagnostic

Dipstik yöntemi için proteinüri sınırı +1 ve üzeri değerler alındı.
21. Morris RK, Riley RD, Doug M, Deeks JJ, Kilby MD. Diagnostic accuracy of spot urinary protein and albumin to creatinine ratios for detection of significant proteinuria or adverse pregnancy outcome in patients with suspected pre-eclampsia: systematic review and meta-analysis. BMJ (Clinical research ed). 2012;345:e4342.

22. Visintin C, Mugglestone MA, Almerie MQ, Nherera LM, James D, Walkinshaw S. Management of hypertensive disorders during pregnancy: summary of NICE guidance. BMJ (Clinical research ed). 2010;341:c2207.

23. Gillon TE, Pels A, von Dadelszen P, MacDonell K, Magee LA. Hypertensive disorders of pregnancy: a systematic review of international clinical practice guidelines. PloS one. 2014;9(12):e113715.

24. Eknoyan G, Hostetter T, Bakris GL, Hebert L, Levey AS, Parving HH, et al. Proteinuria and other markers of chronic kidney disease: a position statement of the national kidney foundation (NKF) and the national institute of diabetes and digestive and kidney diseases (NIDDK). Am J Kidney Dis. 2003;42(4):617-22. 